Прегледни чланак

Csaba Cservák, Ph.D., Associate Professor

Károli Gáspár University of the Hungarian Reformed Church

Budapest

cservak.csaba@kre.hu

\title{
ETHNIC MINORITIES IN HUNGARY
}

Abstract: National and ethnic minorities may be granted personal rights, collective rights and - the greatest benefit-autonomy. Autonomy itself can range from territorial to personal. The legitimacy of the former arises especially where members of an ethnic minority are living together in a territorial block, forming the majority population there. While countries tend to show less reluctance in granting personal autonomy, the notion of territorial autonomy often causes strong aversion. The new Fundamental Law of Hungary has received numerous attacks from the political landscape of Europe, partly from legal professionals, but mainly from politicians. Act CLXXIX of 2011, the legislation currently in effect on national and ethnic minority rights states that „cultural and linguistic diversity are wellsprings of prosperity, rather than division, and Hungary considers the cultural feats of its national minorities an organic part of its cultural heritage”. We can effectively proclaim with a certain sense of pride that Hungarian legislation practically realises cultural autonomy. The current law names the following communal (collective) national minority rights. The new electoral law of Hungary has managed to settle an old debt in creating the possibility of preferential parliamentary representation. National self-governments may run a national minority list, allowing voters to cast their ballots here, instead of traditional party lists.

Keywords: ethnic minorities, personal rights, collective rights, autonomy, new Fundamental Law of Hungary, self-governments, parliamentary representation.

\section{CONCEPT OF ETHNIC MINORITIES}

According to international legal classifications, national and ethnic minorities may be granted personal rights, collective rights and - the greatest benefit - autonomy. ${ }^{1}$

${ }^{1}$ Although there used to be historical periods when the collective aspects of national minority law were completely marginalised. See: FÁBIÁN Gyula-ÖTVÖS Patrícia - Kisebbségi jog I. kötet Komp-press korunk baráti társaság Kolozsvár, 2003. p. 35. 
Autonomy itself can range from territorial to personal. ${ }^{2}$ The legitimacy of the former arises especially where members of an ethnic minority are living together in a territorial block, forming the majority population there. While countries tend to show less reluctance in granting personal autonomy, the notion of territorial autonomy often causes strong aversion. ${ }^{3}$

Examples for personal autonomy can be found in the legal status of Lapps in Sweden, of Danes, Sorbs and Frisians in Germany, of Russians in Latvia and Lithuania and - soon to be detailed - in the case of Hungary's minorities. ${ }^{4}$

Regarding territorial autonomy, further differentiation can be made based on whether this autonomy is embedded into the administrative framework of the state itself. If this isn't the case, success requires a great deal of flexibility and active tolerance on the county's part. For the first category, examples include the Aland Islands in Finland, Corsica in France, as well as Catalonia and the Basque Country in Spain. The second case entails, among many others, the Feröer-Islands in Denmark and 225 Native American communities in the USA. ${ }^{5}$

${ }^{2}$ See: DOMONKOS Endre: Nemzetközi autonómia-modellek és kisebbségi kérdés A katalán regionális autonómia és tapasztalatai Ph.D. értekezés 2010. p. 24-25.

${ }^{3}$ According to certain views, national minorities all but constitute their own distinct category within the separation of powers. Practically speaking, the ombudsman is part of the distribution of powers. The distribution of power, the separation of powers and checks and balances are closely related concepts deriving from coherent theoretical basis. However, their usage is often inconsistent and mixed up frequently in the legal jargon. Therefore, it is necessary to clarify their meanings. Although the theory of the distribution of power is a product of the Age of Enlightenment, its practical manifestation has been in existence for centuries. The divided power is necessarily restricted which is a prevention of the abuse of power and an institutionalized form of the protection against autocracy. Therefore it is unequivocal that the real implementation of the distribution of power had been in the center of efforts, much before it was defined. Contrary to popular belief, Montesquieu didn't establish the classic three branches of powers, but Aristotle did so. He mentioned deliberative body of public affairs, magistrates and judiciary which - considering the complex role of the parliament - is completely equal to the trinity of legislative, executive and judicial powers. Politeia was declared as the appropriate structure of power which is a mixture of democracy and oligarchy. Cicero, in his work The State, committed himself to such type of it inwhich there is an intermediate structure among the monarchy, the rule of aristocracy and the democracy. These two theories can be confidently regarded as a preliminary concept of the distribution of power, because the mixed state can only exist through the precise delimination of the authority of various factors by involving them into the power in sociology-political sense. For several aspect in the theory of the distribution of power, it may be more appropriate to use the concept of the separation of the functions of power instead of the concept of the separation of powers. Because on one hand these patrons of the idea practically envisaged the separation of the function of legislative, executive and judicial powers among different bodies. They fought against the concentration of these three functions in one node, so that their aim was not the abolition of the relation of powers. See: CSERVAK, CSABA: The distribution of Power in Europe and in Central Europe - Separation of Power, Checks and Balances of the Power; Central European Political Science Review, Vol. 15., 2014. Winter

${ }^{4}$ DOMONKOS id. mü. p. 34-37.

${ }^{5}$ DOMONKOS, p. 31-33. 
The new Fundamental Law of Hungary has received numerous attacks from the political landscape of Europe, partly from legal professionals, but mainly from politicians. This begs an important question. Given that Hungary is a sovereign and independent nation, with no other polity possessing a right to influence its internal affairs, objections from other nations would only be justified if our country would infringe upon the rights of their own compatriots. Taking into account the number of grievances Hungarians living outside the country's borders are subjected to, the treatment of national minorities within Hungary itself could be deemed exemplary. The historical constitution ${ }^{6}$ of Hungary already carried significant traditions of minority protection ${ }^{7}$, such as the privileges issued to the Jassic and Cuman peoples $^{8}$, as well as the special legal status of the Saxons ${ }^{9}$ in Transylvania. ${ }^{10}$

Act CLXXIX of 2011, the legislation currently in effect on national and ethnic minority rights states that „cultural and linguistic diversity are wellsprings of prosperity, rather than division, and Hungary considers the cultural feats of its national minorities an organic part of its cultural heritage". ${ }^{11}$

${ }^{6}$ Part of our historical constitution is a collection of lessons written by Saint Stephen, the first king of Hungary to his son, Prince Imre; the sixth of which highlights the role played by national minorities, as well as their correct treatment from the part of the state.

${ }^{7}$ Further reading on minority regulations in a historical context (in Hungarian): BÚZA László - A kisebbségek jogi helyzete MTA Bp. 1930.; A magyar állam és a nemzetiségek - A magyarországi nemzetiségi kérdés történetének jogforrásai 1848-1993 Főszerkesztő: BALOGH Sándor, Napvilág Kiadó Budapest, 2002.; BINDORFFER Györgyi - Kisebbség, politika, kisebbségpolitika - Nemzeti és etnikai közösségek kisebbségi önkormányzati autonómiája Magyarországon Gondolat Kiadó-MTA Szociológiai Kutatóintézet, 2011.

${ }^{8}$ The Cumans received their privileges in 1279 and the Jassics in 1323. They lost these privileges during the Habsburg era in 1702, but purchased them back from Queen Maria Theresa in 1745. This is called redemptio, or self-redemption. Their administrative privileges endured as long as the administrative reform of 1876. In 2014, the Hungarian parliament designated May 6 - the day Maria Theresa signed the document affirming the redemptio in 1745 - the memorial day of Jassic-Cuman self-redemption (Resolution 4/2014. (II. 7.)).

${ }^{9}$ The Transylvanian Saxons settled in Transylvania during the reign of Géza II (r. 1141-1161). The Andreanum, their document of privileges originates from 1224, the reign of Andrew II. Also called Goldener Freibrief by the Saxons, the Andreanum granted all land between Szászváros (current-day Orăștie) and Barót (current-day Baraolt) to the Saxons and designated the Hungarian king and the count of Szeben (current-day Sibiu) their principal judges. The ruler was not allowed to give out the lands of the Saxons to anyone else and also granted the Saxons the right to select their own priests and judges. In exchange, they were required to pay a monetary tax, provide quarters and create a significant (around 500-strong) military force, when necessary. (See: Erdély és népei. Bp., 1941. (MAKSAY Ferenc: A szászság megtelepülése) - HANZÓ Lajos: Az erdélyi szász önkormányzat kialakulása. Szeged, 1941.).

${ }^{10}$ It is to be noted that Hungarian legislation bore a pioneer role in an international context regarding minority protection, especially with its 16 th-17th century policies guaranteeing the rights of religious minorities. See: FARKAS György Tamás: A nemzetiségek alkotmányos jogállása Magyarországon, különös tekintettel a nemzetközi jog Hazánk szempontjából releváns jogforrásaira. Kézirat, Budapest, 2014. p. 15-16.

${ }^{11}$ See the preamble of Act CLXXIX of 2011. The text of the law here harkens back to the lessons of Saint Stephen referring to national minorities as an enrichment to our country and its culture. 
The new law in Hungary replaces the former terminology of „minority” with „national minority", due to previous resentment about the Roma community being referred to as an ethnic minority group, as opposed to national minorities with nations of their own. „National minority” intends to signify that the group in question receives its privileges not only because it constitutes a numerically inferior group within society, but also because it is valuable to the nation. This value is something unique and distinct from the majority population; the cultural nuances embodied by the identity, the language and the historical traditions of national minorities. ${ }^{12}$ (That being said, any potential measures of positive discrimination are justified exactly by their low numbers. The disenfranchisement of the majority population, on the other hand, is thankfully almost nonexistent in our time. The very thought is frighteningly alien to the spirit of modern democracy and the rule of law; such as the cases of ancient Sparta and the South African Republic of last century.)

Although it rarely surfaces in public speech, international jurisprudence usually distinguishes three types of minorities:

- those originally having belonged under the jurisdiction of one state, but annexation or border changes forced them under another,

- the inhabitants of a given area before the state of the current majority was founded there, and lastly,

- those who attained their citizenship after immigrating into the country. ${ }^{13}$

It goes without saying that in terms of personal rights, there can be no differentiation between individuals across these groups. When it comes to collective rights, however, further protection is necessary in the order of the list above, as justified by the more solidly formed identities of the former groups, not to mention their potential historical grievances, such as those of the Hungarians who found themselves outside the country's current borders. While under a democratic rule of law, nobody may be discriminated against based on their ethnic origins, it is important to note that a state's decision on which groups it favours with what benefits, particularly autonomy itself, remains a matter of efficiency and viability. (Jurisprudence could further diversify these categories, such as whether or not the home country of a national minority itself hosts a minority consisting of the other country's compatriots. Under these terms, Hungarians and Romanians are effectively mutual minorities. It is also an important consideration whether a minority possesses a mother country at all, the lack of which necessitates even steadier protection. ${ }^{14}$ )

${ }^{12}$ See: Act CLXXIX of 2011, Section 1, Subsection (1).

${ }^{13}$ SZABADFALVI József: Nemzetállam és szuverenitás (In.: Államelmélet, szerk.: TAKÁCS Péter. Bíbor Kiadó, 1997. Miskolc) p. 137.

${ }^{14}$ The external support of national minorities can naturally be amplified by way of heavy cooperation with their mother country. This is at its most efficient when the two countries border each other. See: FEJES Zsuzsanna: Határok nélkül? A határon átnyúló együttmüködések jogi és közigazgatási környezete Európában és Magyarországon, Budapest, Akadémiai Kiadó, 2013. p. 
Regarding national minority rights, the author classifies them as either positive or negative rights. In this context, negative rights are understood as a lack of prohibition on the support a minority group can receive from its mother country. In the 21st century, it is unacceptable that possessing, for example, Hungarian citizenship would forfeit its bearer's citizenship in the country of their residence. It should be a given, at least, that states refrain from restricting the ability of their national minorities in maintaining contact with their brethren. (We are given an interesting synthesis between the issuing of citizenship to compatriots living abroad and the protection of national minorities in a recent Spanish proposal that endeavours to grant favourable citizenship acquisition procedures to the descendants of Sephardic Jews expelled during the 16th century. ${ }^{15}$ )

Although it remains exceedingly hard to vindicate minority rights in an international context ${ }^{16}$, a state's willingness to provide and reinforce these rights beyond the bare minimum on its own initiative is a hallmark of its progressiveness.

The former Minority Act of Hungary stood on legal principles roughly identical to the current one. Accordingly, national minorities are ,all groups of people who have lived in the territory of Hungary for at least one century, who represent a numerical minority in the country's population, whose members are Hungarian citizens, who are distinguished from the rest of the population by their own languages, cultures and traditions, who demonstrate a sense of belonging together that is aimed at preserving all of these and at expressing and protecting the interests of their historical communities". ${ }^{17}$ The new legislation preserved the previously existing list of thirteen official minorites in its entirety, composed of the Bulgarian, Greek, Croatian, Polish, German, Armenian, Roma, Romanian, Ruthenian, Serb, Slovak, Slovene and Ukrainian communities..$^{18}$ These national minorities enjoy full legal equality. ${ }^{19}$ On the other hand, international treaties also

239 and FEJES Zsuzsanna: Határtalan lehetöségek: az együttmüködés jogi feltételei a magyar-román-szerb hármashatár mentén, In: SOÓS Edit-FEJES Zsuzsanna (szerk.) Régió a hármashatár mentén. p. 158, 2010 Szeged, Szegedi Tudományegyetem Állam- és Jogtudományi Kar, p. 103-118.

15 This proposal ended up being active legislation. See: http://www.hirado.hu/2014/02/09/ szefard-zsidok-leszarmazottai-spanyol-allampolgarok-lehetnek/

${ }^{16}$ Univerzális szinten a nemzetközi jog egyetlen pozitív jogi, tehát kikényszeríthető nemzetiségi jogi jogforrása a Magyarországon az 1976. évi 8. tvr.-el kihirdetett 1966-os Polgári és Politikai Jogok Nemzetközi Egyezségokmány 27. cikke. Ennek értelmében: olyan államokban, ahol a nemzeti, vallási vagy nyelvi kisebbségek élnek, az ilyen kisebbségekhez tartozó személyektől nem lehet megtagadni azt a jogot, hogy csoportjuk más tagjaival együttesen saját kultúrájuk legyen, hogy saját vallásukat vallják és gyakorolják, vagy hogy saját nyelvüket használják. See: FARKAS 2014. id. mü p. 30-31.

${ }^{17}$ See: Act CLXXIX of 2011, Section 1, Subsection (1).

${ }^{18}$ See: Act CLXXIX of 2011, Appendix 1.

${ }^{19}$ As a curiosity, a Ministry of Interior draft in 1992 - while leaving the rest of them in a status similar to the current one - intended to classify Gypsies, Armenians and Jews as ethnic, rather than national minorities, with less numerous privileges. This was met with great outrage 
created a group of so-called ,chartal minorities" in Hungary. This group includes the Croatian, German, Romanian, Serb, Slovak and Slovene minorities, as well as Gypsies speaking Romani or Boyash as their first language; their legal protection ${ }^{20}$ being a result of the signing of the European Charter for Regional or Minority Languages. ${ }^{21}$ (This was extended in 2008 to include the Romani and Boyash languages.) ${ }^{22}$

The current law lists Bulgarian, Greek, Croatian, Polish, German, Armenian, Roma/Gypsy (Romani and Boyash, hereinafter: Roma), Romanian, Ruthenian, Serbian, Slovakian, Slovenian and Ukrainian as national minority languages. Within the Roma and the Armenian communities, the Hungarian language is also counted as such. ${ }^{23}$

Consequently - even though practice on the matter is less than consistent we can distinguish between the protection of national minorities, and that of their languages. The law takes note of the fact that for many Roma and Armenians, Hungarian is their true mother language. (The question begs itself whether the possession of a distinct language can even be a requirement to being categorised as a national minority.)

The list is, of course, a relative one, but it certainly stands to reason that these thirteen national minority groups preserved the rights they formerly acquired. The inclusion of additional national minority groups is also a possibility. Taking into account our common historical traditions and values, one could rightfully ponder why Italians were ranked below the other thirteen in importance. Certain organisations - arguing for the general sympathy felt towards Hungary in many Turkic countries - suggested the possible inclusion of Turks as well. As is natural after a 150-year period of occupation, there are Hungarians with recognised Turkish ancestry. The previous law already allowed an ethnic group with at least a hundred-year presence and a thousand signatories to petition for official recognition as a national minority. ${ }^{24}$ This was taken up on, for example, by the Italians ${ }^{25}$, the Aegean Greeks and the Russians ${ }^{26}$, and one group even purported to be Huns

and the Jewish community - upon its own request - ended up being deemed a religious, rather than a national minority. (See: multiple chapters of BINDORFFER id. mü).

${ }^{20}$ Further reading on the role of the European Charter for Regional or Minority Languages in the international system of minority protection: SZALAYNÉ SÁNDOR Erzsébet - A kisebbségvédelem nemzetközi jogi intézményrendszere a 20. században Gondolat kiadói kör Budapest 2003.

${ }^{21}$ See: Act XL of 1999, Section 3.

${ }^{22}$ See: Act XLIII of 2008 , Section 3.

${ }^{23}$ See: Act CLXXIX of 2011, Section 22, Subsection (1).

${ }^{24}$ See: Act LXXVII of 1993, Section 148, Subsection (3).

${ }^{25}$ Although the Italians were granted the National Electoral Commission's (OVB) permission in January 2008, they were unable to collect the minimum amount of signatures necessary on time. See: http://www.nvi.hu/nepszav08/ovb/hu/osszefoglalok/20080825.pdf, downloaded: September 16, 2014.

${ }^{26}$ The Russian request foundered on formalities, because despite being mandated to do so by law, the National Electoral Commission neglected to formally request the opinion of the Hungarian 
while issuing the request. ${ }^{27}$ Realisation was met with difficulties, however; illustrating the point that the popular initiation of the process isn't nearly as effective as outright legal codification through parliament. (In the absence of this hundredyear requirement, even the Chinese could step up with a claim. ${ }^{28}$ The question is: where do we draw the line in the name of efficiency?)

The choice of which ethnic group to imbue with the recognition and protection of the law is a difficult one. To illustrate that, let us put forth a number of rhetorical questions. What is the main distinguishing factor between the already recognised national minorities and the rest of them listed above? The number of citizens identifying themselves with them? It is worth noting here that in this regard, different cultures present different attitudes. (For instance, whether it's important for someone to be German, or it's merely a case of possessing a German surname.) Are we only to study the number of indigenous Poles, or do we also count those who immigrated in the past fifty years? Can we discriminate against Italians and Turks whose original populations are low, but recently received a significant boost? ${ }^{29}$ For some, it is perhaps only their names (or a family legend) that reminds them of their origins ${ }^{30}$, and even in the „Thirteen”, many might only have responded positively for the sake of the benefits provided by the national minority status. These questions all highlight the relative and nuanced nature of these categories.

To continue with the questions, can it be a deciding factor whether the mother country of a given ethnicity is/was bordering Hungary? Despite many centuries of neighbourhood, Poland no longer falls into this category, and even Italy was once bordering the western reaches of the Kingdom of Hungary, with many joint rulers down the line. ${ }^{31}$ Not only was Turkey a neighbour, it even annexed our

Academy of Sciences (MTA). (MAJTÉNYI Balázs: Nemzeti és etnikai kisebbségi jogok, In.: JAKAB András: Az Alkotmány kommentárja, Századvég Kiadó, 2009. Budapest) p. 2408-2412.

${ }^{27}$ See: Resolution 32/2005. (IV. 27.).

${ }^{28}$ Interestingly, after helping to crush the Boxer Rebellion in 1901, the Austro-Hungarian Empire managed to acquire a concession of roughly a hundred hectares in the city of Tianjin, thus creating a „quasi-colony” with about 25,000 Chinese locals.

${ }^{29}$ It is even less justified to exclude the Turkish and Italian people from the list of beneficiaries based on population data. Taking into account recent arrivals, some of the established national minorities already fall into comparative numerical inferiority (see:.http://www.ksh.hu/docs/ hun/xftp/idoszaki/nepsz2011/nepsz_09_2011.pdf; downloaded: September 15, 2014).

30 There are many Hungarians with Italian names, including notable jurists and composers. A few families also cultivate their Turkish roots from Ottoman times. The family of light cavalry lieutenant general Ferenc Czungenberg, originating from Csonka Bey, is but one of the many examples. See: BARCY Zoltán-SOMOGYI Győző: Magyar huszárok, Móra Ferenc Könyvkiadó, 1987. Budapest, p. 26), see: http://www.kislexikon.hu/olaszok_hazankban.html .

31 ,Almost immediately after the birth of the Kingdom of Hungary, settlers (called hospes in Latin) started pouring in from the west continuously. A testament to their early presence is 35 settlement names with the Németi- prefix (meaning German) and 8 with Olaszi- (Italian), originating 
current capital under Suleiman I. Which brings us to our next point: can it possess any relevance whether the role of a given people has been positive in our history? Can we distinguish based on this? This is also a highly relative matter, especially since contemporary foreign affairs may suddenly boost the importance of any country significantly. Let us add that the role of our current neighbours also wasn't always a positive one, but we must look forward, not backward. To summarise: based on the above, it is the claims of Italians and Turks that would especially merit acknowledgement.

After the fall of Communism, the participation of minorites in public affairs, as guaranteed by the Constitution, was intended to be realised in the form of a collective ombudsman, into which all thirteen minorities were to delegate one representative. Later, political speech effectively washed together representation in public affairs with political representation, constantly stressing its need and importance. Parallel to this, an ombudsman responsible for minority affairs was created..$^{32}$ The holder of this office was nominated by the president(ennyi, ugye?) and confirmed by a two-thirds majority in parliament. In practice, however, different interpretations on certain fundamental rights kept occurring between the general ombudsman and the minority affairs ombudsman regarding grievances issued by minority citizens. (It is difficult enough to ascertain whether these offences even happened due to their ethnic origins.) Under the aegis of the new Fundamental Law, the office of the ombudsman became monocratic (,one-headed”). ${ }^{33}$ This brings it under a unified direction, with the role of a separate minority affairs ombudsman being taken over by a deputy nominated by the singular ombudsman

from the 11th and 12th centuries. They were dispersed around the country, depending on when they arrived and where they were needed. The newcomers were Germans, Italians (which, under medieval terminology, also included Walloons) Czechs, Poles and other neighbouring peoples. Most of them were farmers, but merchants also arrived in plentiful numbers. It was the latter group that came to form the core of the newly founded cities.

Among the more minor groups were those Italians that came to the Kingdom of Hungary to participate in trade and other financial matters during the 14th and 15th centuries. (During this era, Italians were living in virtually every country in Europe.) In 1402, the Italian community in Buda supported Ladislaus of Naples over Sigismund of Luxemburg during their succession conflict, for which the victorious Sigismund cast many of them into prison. Local Germans exploited the opportunity and largely took over their chamber offices, allowing them to control the mining operations of gold, silver and copper. The Italians soon regained these posts, and from that point forward, these two groups alternately controlled the mines of Hungary.” See: DRASKÓCZY István: Kisebbségek az Árpád-kori Magyarországon, Draskóczy http://epa.oszk.hu/00400/00462/00007/4. htm, downloaded: September 16, 2014).

${ }^{32}$ The office of the ombudsman of minority affairs was created by the Act on the Rights of National and Ethnic Minorities in 1993 (Act LXXVII of 1993). According to this, the ombudsman of minority affairs was essentially subject to the same regulations as the general ombudsman (Act LIX of 1993). Because the election of the first minority affairs ombudsman required a two-thirds majority in parliament, it only came about in 1995 , for various political reasons.

${ }^{33}$ See: The Fundamental Law of Hungary, Article 30, Section (1). 
himself and confirmed, as before, through a two-thirds parliamentary vote. This deputy commissioner of fundamental rights is responsible for the legal protection of national minorities living in Hungary, monitoring their situation, guaranteeing their rights and taking all measures prescribed by law. In the event that the deputy possesses a degree of independence - the Hungarian law currently in effect allows for this - this model is well-suited to provide efficient legal protection for national minorites. (We can add here that even though the situation of Hungarians living there would strongly justify it, neither the Slovakian, nor the Romanian constitution has yet created such an institution. ${ }^{34}$ )

In one of his previous publications, the author of this work suggested the inclusion of minorities in a theoretical second chamber of parliament, with a serious role to play there. ${ }^{35}$

\section{CURRENT LEGISLATION ON NATIONAL MINORITY RIGHTS IN HUNGARY}

Observing the individual aspect of national minority law, it is clear that the right of the individual to identify with a national minority is exclusive and inalienable. No one can be forced to make a statement regarding their identification with national minorities, although certain legislation may require such definitive statements in order for the citizen to exercise certain national minority rights.

Personal national minority rights are the following. The right of national identification and the right to declare oneself belonging to a national minority with certain exceptions explicitly stated by the law - do not prevent the recognition of dual or multiple national identities. Any person belonging to a national minority has the right to:

${ }^{34}$ In the academic literature of constitutional law, the ombudsman has long constituted a widely accepted category. Persons holding this position are given a diverse array of titles worldwide. In Hungary, they are the Commissioner for Fundamental Rights, in the Ukraine the Parliament Commissioner for Human Rights, and in Poland - until recently - the Advocate for Citizens' Rights. They are named High Commissioner for Human Rights in the Russian Federation and in Azerbaijan, while Spain, Czechia and Slovakia use 'Defender of the People' or 'Public Defender of Rights'. In Albania and Croatia, it is the People's Advocate, and in Macedonia, the People's Attorney. France, Belgium and Luxembourg call it Mediator. Portugal refers to the post as 'Justice Provider'.

The office was first installed in early 1700 s Sweden, though similar state functions had already existed earlier. International organisations advocating for human rights (among others) routinely call upon their member states to create such offices. Both the Council of Europe and its handbook dealing with administrative requirements touch upon the topic, with the Council having issued an official recommendation to establish ombudsmen.

See: CSERVÁK Csaba: Az ombudsmantól az Alkotmánybiróságig - Az alapvető jogok védelmének rendszere, Budapest, Licium-Art, 2013. p. 45-48, p. 241.

${ }^{35}$ See: CSERVÁK Csaba PhD dissertation 2010. p. 89-90. 
- use their mother language in both spoken and written word, to discover, preserve, cultivate and pass on their history, culture and traditions;

- learn their mother language, to participate in public education and cultural events held in that language;

- equal opportunity in education and cultural services, which the state is obligated to provide for with efficient measures;

- special protection of their personal data regarding their national minority status, as detailed in provisions laid down in a specific law. ${ }^{36}$

Members of a national minority are entitled to use their family- and personal names according to the rules of their mother language, which entails naming and registering their children the same way. In addition, members of a national minority must have their national family traditions respected, and be allowed to cultivate their familial connections, conduct their family celebrations in their own language and organise any religious ceremonies pertaining to the above. Their participation in public life - based on their national identity - may not be restricted. Finally, within the appropriate legal boundaries, they are allowed to form associations and political parties in order to express and defend their collective interests.

We can effectively proclaim with a certain sense of pride that Hungarian legislation practically realises cultural autonomy. The current law names the following communal (collective) national minority rights. To preserve, cultivate, strengthen and pass on their identity, to safeguard and advance their historical traditions and their language, and to protect and prolificate the material and spiritual aspects of their culture are all inalienable rights of national minorities.

While practicing their naming rights, national minorities are also entitled to use historical settlement names, street names and geographical markers. It is also within their right to create and direct certain institutions, or to take them over from other administrative units, as well as to organise national minority kindergartens, primary schools, secondary- and high schools, specialised schools and higher education. In addition to this, their respective national self-governments may initiate and participate in the organisation of supplementary national minority education.

Within the limits of its laws, Hungary guarantees the rights of national minorities to hold undisturbed public events and celebrations, to maintain and preserve their architectural, cultural, funerary and religious traditions, and to use their various symbols. National minority organisations may also establish and maintain extensive and direct international connections.

\footnotetext{
${ }^{36}$ Regarding information privacy rights, the current minority act allows citizens to voluntarily and anonymously identify as members of a national minority during official acts of data collection. According to Act CXII of 2011 on Informational Self-Determination and the Freedom of Information, this data can be used when determining the amount of government support granted to national minorities and during the process of supervising the proper allocation these resources.
} 
National minorities have the right to access and relay information in their own language, whether it be through traditional press or modern mass-communication and media services. The state is obligated to provide access for recurring national minority-language broadcasts in both radio and audiovisual format in a way that enables full access to such services in all relevant regions inhabited by the respective national minority.

Local national minority self-governments - under the principle of cultural autonomy - have, among others, the following matters in their jurisdiction:

- the creation of national minority institutions,

- the creation of awards and the determination of the requirements and rules of their issuing,

- the creation of national minority scholarships and contests.

In addition to the above and excepting matters purely within the purview of central authorities, local national minority self-governments may take on voluntary tasks pertaining to educational and cultural administration, local traditional and electronic media, the cultivation of traditions, the dissemination of information, social integration, cultural-, social- and youth activity administration, public employment programmes, urban planning and other areas.

The new electoral law of Hungary has managed to settle an old debt ${ }^{37}$ in creating the possibility of preferential parliamentary ${ }^{38}$. representation ${ }^{39}$ National self-governments may run a national minority list, allowing voters to cast their ballots here, instead of traditional party lists. ${ }^{40}$ With a little simplification ${ }^{41}$, the process can be summarised in that a preferential mandate is acquired when a national minority list manages to attain one-fourth of the proportional quota (calculated from the number of votes per mandate).$^{42}$ This presents an extraordinary oppor-

${ }^{37}$ See: FARKAS György Tamás: A nemzetiségek parlamenti képviselete Hazánkban és a környezö országokban, (szerk: Erik STENPIEN - MISKOLCI Bodnár Péter) Jog és Állam X. Jogász Doktoranduszok Országos Szakmai Találkozója 2015/20. szám KRE-ÁJK Budapest, 2015. p. 16-18.

${ }^{38}$ Section 68, Subsection (1) of the Constitution of Hungary, modified by Act XXXI of 1989, defined national minorities as constituent elements of the Hungarian state (this terminology was later copied by the Fundamental Law replacing the Constitution). From this wording, in Resolution 35/1992 (VI. 10.), the Constitutional Court of Hungary (AB) ruled that national minorities are entitled to parliamentary representation and found the legislature's neglect in providing for it unconstitutional. This was only recently remedied, when an electoral law (Act CCIII of 2011) made it possible to create national minority lists during general elections. This already underwent „live testing" during the parliamentary elections of 2014.

${ }^{39}$ Immediately after the fall of Communism, a law was enacted that (would have) provided national minorities with parliamentary representation, but it was repealed before it could be realised. See: FARKAS 2014. id. mü. p. 63-64.

${ }^{40}$ See: Act CCIII of 2011, Section 12, Subsection (2).

${ }^{41}$ See in greater detail: CSERVÁK Csaba: Választási rendszerek-és az új magyar megoldás (In: szerk. RIXER Ádám: Válogatott közjogi tanulmányok Magyarország Alaptörvénye tiszteletére, KRE-ÁJK, Budapest, 2012.), p. 291-307.

42 See: Act CCIII of 2011, Section 16/D. 
tunity. One of the great questions of elections to come will be the extent to which national minorities will be able to influence public life thanks to this policy. ${ }^{43}$

Our country can be proud of its legislation on national minority protection. This, of course, doesn't mean that the system - according to the needs of national minorities and without going against the will of the majority - cannot be improved even further. Cooperation with national minorities isn't purely a matter of law, but also diplomacy. In treating them well enough, the state will be able to utilise its national minorities in international mediation. ${ }^{44}$

${ }^{43}$ The presence of a voting system favouring proportionality provides a crucial benefit for national minorities in the pursuit of their interests. According to the time-honoured view, in a proportional/party-list system, citizens are only entitled to vote on party-created lists, with no ability to influence who their vote personally benefits. Is this truly the case, even today?

The question of vote structuring determines how many votes a single citizen is allowed to cast, and how. There exist single-vote and multiple-vote systems. The latter can be broken down further into preferential models, models that enable the cumulation of votes and models that allow for vote splitting. In the first case, voters are entitled to make modifications on the party list, swaying them towards their preferred candidate. In the second case, it is possible to reinforce the position of one candidate by allocating them extra votes, further increasing their chance to gain a mandate. Lastly, the third model opens up the aforementioned possibilities in the case of lists as well.

In terms of the right of voters to bring about such modifications, the various preferential systems paint a colourful picture worldwide. Only one preferred candidate can be designated in Austria, while the same number is four in Italy. It is possible to split votes in Switzerland and Luxemburg, giving each voter as many votes as there are mandates to gain in a district, which can be cast for different parties. By now, in most Western European countries, allowing citizens to influence party list compositions has become common practice. In Belgium, the influence of preferential votes determines almost fifty percent of the order of candidates on party lists. The German system remains almost the only one disallowing this practice, its single districts purporting to substitute for the lack of choice between individual persons.

Since the fall of Communism, a number of Central-Eastern European countries also implemented ways to create more flexible party lists. In Poland, citizens must select a name from a regional party list, an act with which they also cast their vote for that candidate's party itself. Similarly, the Slovene model divides electoral districts into single-member constituencies, in which single candidates are also the nominees of their respective party lists. Again, voting for a candidate is also voting for a party list. Mandate distribution is based on the proportion of ballots cast for each party list, giving successfully acquired mandates to candidates having won the greatest number of votes on their respective lists. Czechia and Slovakia also allow their voters to influence the prearranged order of party lists. Each citizen may designate four candidates they have especial preference for. Such preferential votes will result in the acquisition of a mandate in the event that at least ten percent of voters in the district cast such a vote, and the candidate in question managed to seise at least ten percent of all the preferential votes his party received. Austria operates similarly, except it requires an amount of preferential votes equal to at least half of what is necessary for a single district mandate, or one-sixth their total number cast in their party's favour. Finland's „flexible list" enables party list rankings to be molded entirely by voter will; on each ballot, the candidates of parties are merely displayed in alphabetical order.

${ }^{44}$ This may well occur in the Ramil Safarov case, which caused a diplomatic gaffe between Hungary and Armenia. 
As a conclusion, we can consider the level of national minority protection more than sufficient and in tune with our historical traditions in this regard. Consensus on the need to preserve this protection is wide-scale. It goes against the values of every decent person to offend minorities. The problem begins only when certain people use their national (minority) status as a shield against completely legal procedures. This custom can potentially erode said consensus on minority protection. From this point forward, however, it is their personal behaviour, and not their origins that falls subject to rightful criticism. 
Др Чаба Червак, ванредни иррофесор

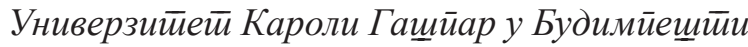

Правни факулиетеи

cservak.csaba@kre.hu

\section{Етничке мањине у Мађарској}

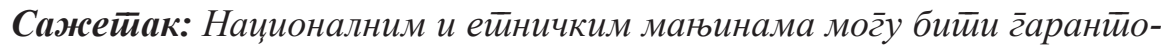

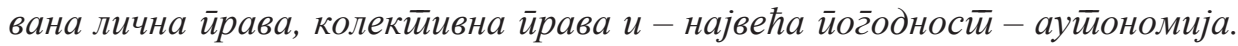
Ауйономија сама йо себи може битии у расиону од иерииторијалне до иерр-

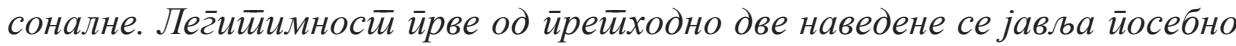
када чланови једне етиничке мањине живе заједно у терииторијалном блоку, образујући већину йойулаиије на ӣом йодручју. Док државе имају обичај да иоказују мање невољностии у гаранимовању иерсоналне ауйономије, иојам

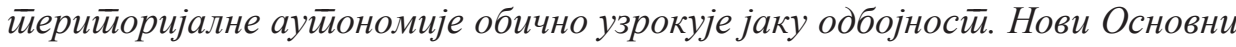
закон Мађарске иррейриео је бројне найаде од стиране йолиииччког̄ окружена Евроие, делом од сіиране сииручне јавносиии, али већином од сииране йоли-

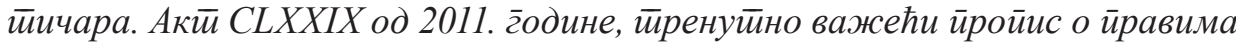
начионалних и етиничких мањина ӣройисује да ,кулйурна и језичка различи-

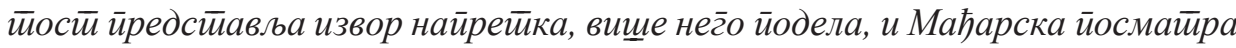
кулйурна йостиигенућа својих начионалних мањина као орг̄ански део свог̄

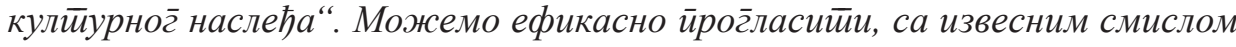
йоноса, да мађарски ирроииси ирракииччно реализују куличурну ауйономију. Тренуйни закон именује следећа комунална (колекииивна) ирава наџионалних мањина. Нови изборни закон Мађарске усиео је да оконча сйару дилемуо

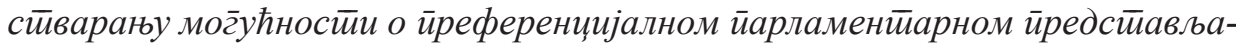
юу. Начионалне самоуираве могуу кандидоваиии листиу националних мањина, давајући могуућности гласачима да дају свој гллас овој листии, уместио ӣради-

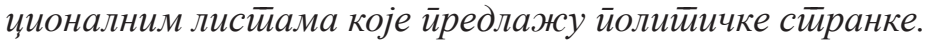

Кључне речи: етиничке мањине, лична йрава, колектиивна йрава, ауйономија, нови Основни закон Мађарске, самоуйрава, йарламенйарно ирредстйвљање.

Датум пријема рада: 09.12.2017. 